\title{
Low IgE monoclonal gammopathy level in serum highlights 20-yr survival in a case of IgE multiple myeloma
}

Michael J. Hayes ${ }^{1}$, John L. Carey ${ }^{2}$, John C. Krauss ${ }^{3}$, Deborah L. Hedstrom ${ }^{4}$, Ronald L. Gulbranson ${ }^{4}$, David F. Keren ${ }^{4}$

${ }^{1}$ Department of Pathology, The University of Michigan, Ann Arbor, MI; ${ }^{2}$ Department of Pathology, Henry Ford Hospital, Detroit, Ml; ${ }^{3}$ Department of Internal Medicine, St Joseph Mercy Hospital, Ann Arbor, Ml; ${ }^{4}$ Warde Medical Laboratory, Ann Arbor, MI, USA

\begin{abstract}
This report describes the diagnosis, follow-up, and problems measuring serum immunoglobulin $E$ (IgE) levels in a case of IgE myeloma with 20-yr survival. Serum and urine protein electrophoresis, immunofixation, and the $\mathrm{N}$ Latex IgE test were used to characterize the monoclonal proteins. The diagnosis of multiple myeloma in a 56-yr-old man was based on $5.4 \mathrm{~g} / 24 \mathrm{~h}$ of monoclonal free lambda chain in urine and bone marrow findings of $23.5 \%$ plasma cells (19\% mature and $4.5 \%$ atypical). IgE lambda monoclonal protein in serum measured $506000 \mu \mathrm{g} / \mathrm{L}(210833 \mathrm{IU} / \mathrm{mL})$. The lack of other clinical findings of multiple myeloma places this case in the category of 'smoldering or indolent myeloma'. Measurement of serum lgE levels was complicated by the need to predilute serum to avoid antigen excess. Following chemotherapy, the patient went into clinical remission, eventually dying of complications of emphysema. This case expands the recognized clinical spectrum of IgE multiple myeloma.
\end{abstract}

Key words immunoglobulin E; multiple myeloma; immunofixation; Bence Jones protein; capillary zone electrophoresis

Correspondence David F. Keren, MD, Medical Director, Warde Medical Laboratory, 300 West Textile Rd, Ann Arbor, MI 48108, USA. Tel: +1 734214 0300; Fax: +1 734913 6060; e-mail: kerend@wardelab.com

Accepted for publication 30 December 2006

doi:10.1111/j.1600-0609.2007.00825.x

Immunoglobulin E (IgE), first isolated by using the ragweed $\mathrm{E}$ antigen, for which it is named, modulates allergic and atopic conditions, responds to helminthic and respiratory infections and may play a role in chronic inflammatory diseases (1-5). The IgE-secreting subtype of multiple myeloma, first reported in 1967, is an extremely rare disease, representing only $0.01 \%$ of all cases $(1,6)$. Including our patient, originally reported in 1984 (7), there have been 43 cases reported (8), along with one case of IgE monoclonal gammopathy of uncertain clinical significance (MGUS) (9).

As with other isotypes of myeloma, IgE myeloma has clinical features of bone pain, osteolytic bone lesions, hypercalcemia, elevated erythrocyte sedimentation rate, infections, weakness, fatigue, and weight loss $(4,10)$, but a higher rate of plasma cell leukemia, anemia, hepatosplenomegaly, osteosclerotic bone lesions, renal insufficiency, respiratory infections, and Herpes Zoster (1, 4, 7, $8,11,12)$. It has also been reported in association with amyloidosis (1), cryoglobulinemia, and hyperviscosity syndrome (13). Most patients with IgE myeloma have more severe disease with shorter survival times than $\operatorname{IgG}$ and $\operatorname{IgA}$ myeloma $(1,7,8)$. Exceptional survival times have also been reported in other isotypes, including a case of IgD myeloma with an 8-yr complete remission to date (14). The average survival time for IgE myeloma in a review of 35 cases was only 16 months, compared with an average of 30 months in other cases of myeloma (11).

\section{Case report}

The patient originally presented in 1983, a 56-yr-old man complaining of weakness, lower back and leg pains, as well as a 'waxy feeling' in his muscles. These symptoms had been present for about a year. He had a normal hemoglobin, white blood cell count, blood urea nitrogen, creatinine, calcium, and uric acid. Although osteoporosis was present, he had no lytic bone lesions. He had 
proteinuria totaling $5.4 \mathrm{~g} / 24 \mathrm{~h}$, identified as virtually entirely monoclonal free lambda light chain by immunofixation (IFE).

A bone marrow aspirate contained 19\% mature plasma cells and $4.5 \%$ atypical plasma cells. The patient was diagnosed with plasma cell myeloma at that time. He fulfilled both a major (over $1 \mathrm{~g} / 24 \mathrm{~h}$ Bence Jones proteinuria) and a minor (10-30\% bone marrow plasma cells) of the current WHO criteria for the diagnosis of myeloma (15).

Serum IFE identified a monoclonal IgE lambda protein that measured $506000 \mu \mathrm{g} / \mathrm{L}(210833 \mathrm{IU} / \mathrm{mL})$ by an IgE-specific radioimmunoassay. Because of the patient's symptoms suggestive of amyloidosis, rectal and muscle biopsies were performed but were negative for amyloid (by Congo red staining). Studies for light chain deposition disease were not performed.

Initially, the patient was treated for a year and a half with doxorubicin (Adriamycin), cyclophosphamide (Cytoxan), melphalan (Alkeran), and prednisone (Deltasone). Toward the end of this chemotherapy regimen, he experienced a myocardial infarction, which was treated with stenting. Following this episode, the patient also developed chronic episodic atrial fibrillation that persisted until his death. However, he achieved relief from his presenting symptoms and serologic remission from the myeloma for $5 \mathrm{yr}$.

His IgE blood level relapsed in 1991, but again responded to melphalan (Alkeran) and prednisone (Deltasone). To maintain his serologic remission, the patient was treated with melphalan (Alkeran) and prednisone (Deltasone) for one of every $3 \mathrm{yr}$ between 1991 and 1998.

In addition to IgE myeloma, the patient also had pulmonary emphysema secondary to a history of smoking (which he had discontinued in 1978). By 1997, the patient required oxygen therapy for this. He also had worsening of his episodic atrial fibrillation. $\mathrm{He}$ declined anticoagulation and lipid-lowering therapy. His primary complaint following therapy was chronic fatigue attributed to his cardiopulmonary disease rather than neurologic or other complications of his myeloma.

A magnetic resonance imaging (MRI) performed in April 2002 showed an abnormal signal interpreted as possible infiltration of myeloma in the lumbar vertebrae and in the ischiae bilaterally. However, degenerative disk disease was also present and no biopsy was performed.

In the 6 months proceeding May of 2003, the patient experienced a decrease in his ability to exercise and in his general mobility level, in part related to pain in his legs. Increased muscular tension was noted in the legs on physical examination. By this time, he had an established diagnosis of osteoarthritis, which contributed to his back pain. Specific neurologic symptoms were not identified

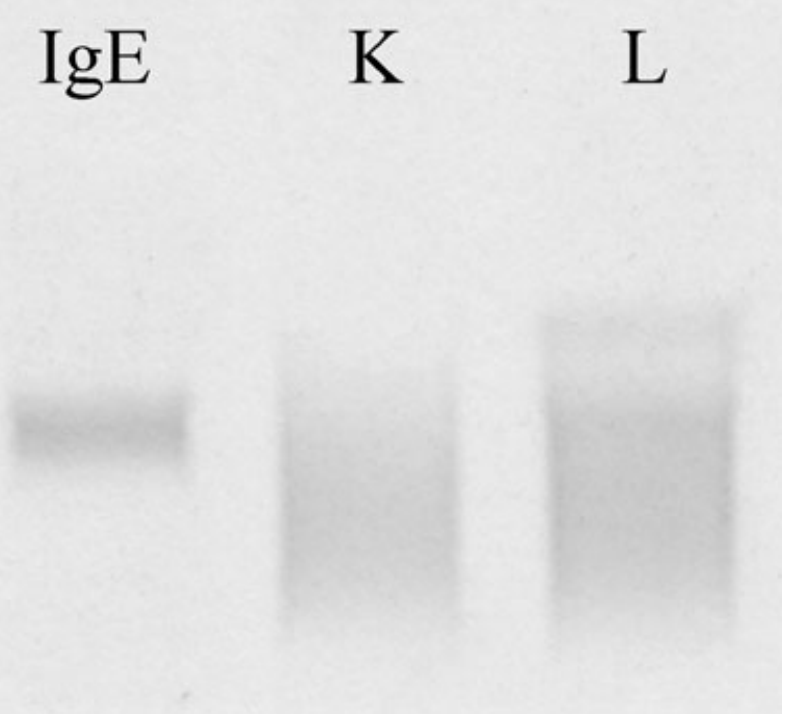

Figure 1 Immunofixation with antisera against IgE, kappa (K), and lambda ( $L$ ) reagents run on patient's serum demonstrates an obvious IgE restriction, a corresponding restriction in the lambda lane, and a more anodal restriction in the lambda lane reflecting the monoclonal free lambda (Bence Jones) protein.

on routine examination, although electrophysiologic studies were not performed.

Available records showed erratic levels of IgE. An IgE level of $1632 \mu \mathrm{g} / \mathrm{L}(680 \mathrm{IU} / \mathrm{mL})$ was reported on $6 / 13 / 02$ that increased to $69502 \mu \mathrm{g} / \mathrm{L}(28959 \mathrm{IU} / \mathrm{mL})$ on $3 / 17 /$ 03 , decreased to $2323 \mu \mathrm{g} / \mathrm{L}(968 \mathrm{IU} / \mathrm{mL})$ on $8 / 1 / 03$, and increased to $270240 \mu \mathrm{g} / \mathrm{L}(112600 \mathrm{IU} / \mathrm{mL})$ on $11 / 5 / 03$ and $636000 \mu \mathrm{g} / \mathrm{L}(265000 \mathrm{IU} / \mathrm{mL})$ on $12 / 18 / 03$. This reflected a problem with antigen excess effect as discussed below. Although his IgE value was $297120 \mu \mathrm{g} / \mathrm{L}$ (123 $800 \mathrm{IU} / \mathrm{mL}$ ) on $4 / 28 / 03$, the IgE monoclonal band was too small to be seen by capillary zone electrophoresis (CZE) of the serum, but it was detected by IFE (Fig. 1).

He died of complications of his chronic cardiopulmonary diseases in 2004. No autopsy was performed.

\section{Methods}

\section{Serum protein electrophoresis}

Samples of serum protein electrophoresis for this report were performed by CZE on the Sebia Capillarys (Sebia, Inc., Norcross, GA, USA) as described previously (16).

\section{Immunofixation}

IFE was performed with Sebia Capillarys system, using agarose gels. IFE assay used specific antisera to $\mathrm{IgG}$, IgA, IgM, IgE, kappa, and lambda. The precipitated 
protein was visualized with acid violet stain. Urine IFE electrophoresis was performed on concentrated urine with antisera against $\mathrm{IgE}$ in addition to kappa and lambda chains.

\section{Measurement of total serum IgE}

IgE was measured by the N Latex IgE test on the BNII Dade Behring Nephelometer (Dade Behring, Deerfield, IL, USA). For this assay, polystyrene particles coated with specific antibodies to human $\operatorname{IgE}$ are agglutinated with serum IgE. The scattering of light passed through the suspension of the agglutinating polystyrene particles is proportionate to the concentration of $\mathrm{IgE}$.

\section{Results and discussion}

At the time of his recent presentation (December 2003), the patient was mildly anemic with a hemoglobin 12.1 (13.5-17.5), hematocrit 36.0 (41-53), and erythrocyte count 3.75 (4.6-6.2). CZE demonstrated a tiny fast gamma restriction (Fig. 2). The serum on 12/18/03 from our patient shown in Table 1 had a total $\mathrm{IgE}$ concentration of $631200 \mu \mathrm{g} / \mathrm{L}(263000 \mathrm{IU} / \mathrm{mL})$. Although this is a relatively small amount in gravimetric terms $(64 \mathrm{mg} /$ dL), it is more than 2000 times the upper limit of the standard curve used in this assay.

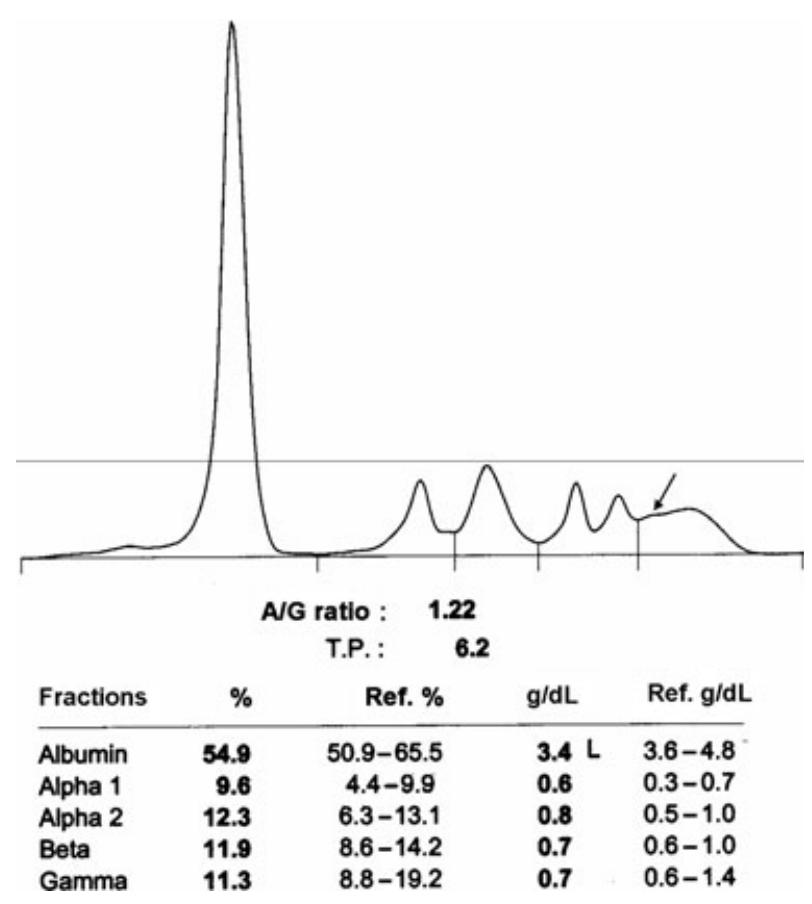

Figure 2 Capillary zone electrophoresis of patient's serum demonstrates a tiny fast gamma restriction (arrow) that corresponds to the small IgE lambda M-protein demonstrated by immunofixation.
Table 1 Effect of predilution on total lgE measurement

\begin{tabular}{ll}
\hline Predilution of serum & Measured $\operatorname{lgE}$ value $(\mathrm{IU} / \mathrm{mL})$ \\
\hline None & 270 \\
$1: 100$ & $>5640$ \\
$1: 400$ & $>22800$ \\
$1: 2000$ & $>113000$ \\
$1: 8000$ & 263000 \\
\hline
\end{tabular}

In performing the total $\mathrm{IgE}$ assay, we noticed that when the patient's serum was examined undiluted, the instrument gave a falsely low reading of $648 \mu \mathrm{g} / \mathrm{L}$ (270 IU/mL). This was due to an antigen excess effect illustrated by our serial dilution study in Table 1 .

Urine IFE and protein electrophoresis demonstrated only a small amount of monoclonal free lambda chain with a mild overflow pattern of proteinuria (Figs 3 and 4). The final 24-h urine sample contained $55 \mathrm{mg} / 24 \mathrm{~h}$.

Our patient's 20-yr course postdiagnosis of plasma cell myeloma is the longest survival reported for a myeloma of the IgE immunoglobulin isotype. By comparison, the longest reported survival in a series of 38 cases (of which 25 had survival times available at the time of print) of IgE myeloma was $8 \mathrm{yr}$ and 3 months, and the median was only $1 \mathrm{yr}(1)$.

Our patient's survival far exceeds that of a recently reported case of $\mathrm{IgD}$ myeloma with an extraordinary complete remission for $8 \mathrm{yr}$ to date, who cleared his monoclonal protein and was negative by MRI after a typical course of chemotherapy (14). Although this has

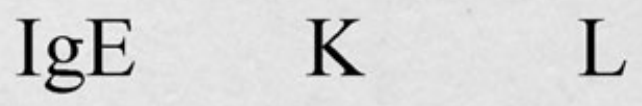

Figure 3 Immunofixation of patient's urine for IgE, kappa, and lambda demonstrates only monoclonal free lambda. 


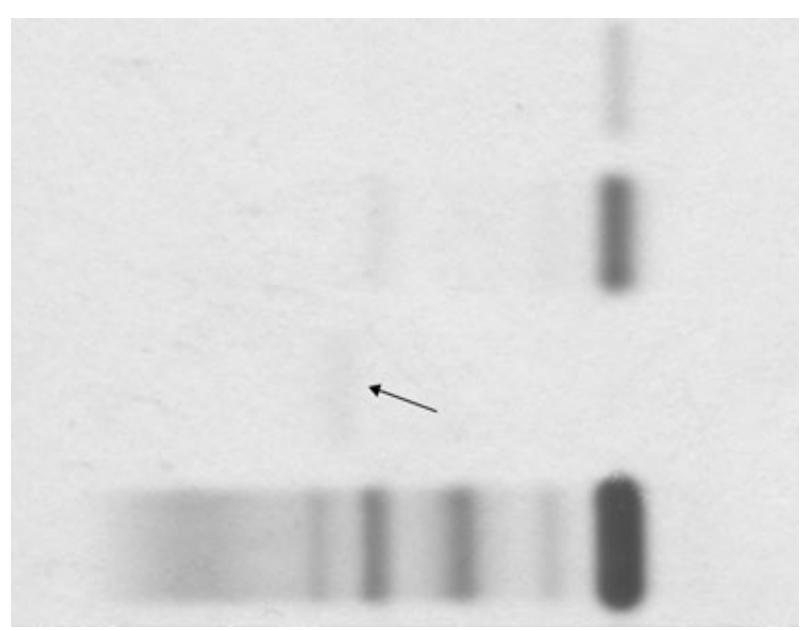

Figure 4 Urine protein electrophoresis is shown with sample control serum (bottam) and two urine samples (top; concentrated 50x) from two other patients. The patient's urine (concentrated 50x) is the third sample with the arrow indicating the monoclonal free lambda chain.

been suggested as a possible example of cure, the length of remission is not yet greatly longer than the $5 \mathrm{yr}$ our patient achieved before serologic relapse and development of a remitting/fluctuating low level of disease as reflected by monoclonal serum IgE levels over the next $15 \mathrm{yr}$.

The extraordinary length of time our patient endured his plasma cell dyscrasia may lead some to question the original classification of this patient's diagnosis. However, our patient fulfilled both a major and a minor diagnostic criterion of plasma cell myeloma. Additional diagnostic features of myeloma were the presence of atypical appearing plasma cells, and a marked elevation (compared with the normal range) of IgE isotype paraprotein.

Our patient also exhibited symptoms suggestive of pathogenic protein deposition in tissues, and although amyloidosis was excluded in a single biopsy (by Congo red staining), light chain deposition disease could have been present in other locations or by immunohistochemical techniques. Notice should be taken of another case of IgE myeloma with amyloidosis in which a rectal biopsy was negative but cardiac and gingival samples taken postmortem were positive for amyloid (by Congo red staining) (1). According to the WHO criteria, any 'myeloma-related' symptoms raise the category of disease from MGUS to smoldering myeloma (15). Our patient's level of plasmacytosis $(23.5 \%)$ alone would also have been enough to raise his diagnosis to smoldering myeloma. However, his lack of other major clinical findings of organ dysfunction would place him in the diagnostic category of 'smoldering or indolent myeloma' according to the recent myeloma management guidelines from the International Myeloma Foundation (17).
The multi-agent chemotherapy, with subsequent doses administered in response to changes in his serum IgE levels that controlled the monoclonal free lambda light chains in his urine, likely contributed to the long survival. However, the chemotherapy alone cannot explain the unusually long survival of our patient, as it was not an unusual therapy regimen for plasma cell myeloma. Unfortunately, no autopsy was performed which could have explained some of the musculoskeletal symptoms that this patient experienced. Although our patient's symptoms and degree of morbidity were far less than that typically seen in myeloma, his length of survival and lack of myeloma-related morbidity during his life expand the scope of clinical findings in patients with an $\operatorname{IgE}$ monoclonal process.

\section{External sources of support}

None.

\section{Conflict of interest}

To the best of our knowledge, none of the authors have conflicts of interest regarding the information reported in this article.

\section{References}

1. Jako JM, Gesztesi T, Kaszas I. IgE lambda monoclonal gammopathy and amyloidosis. Int Arch Allergy Immunol 1997;112:415-21.

2. Ishizaka K, Ishizaka T, Hornbrook MM. Physicochemical proteins of reaginic antibody.V. Correlation of reaginic activity with gamma $\mathrm{E}$ globulin antibody. J Immunol 1966;97:840-53.

3. Editorial IgE immunoglobulin. Br Med J 1973;4:250-1.

4. Ogawa M, Kochwa S, Smith C, Ishizaka K, McIntyre OR. Clinical aspects of IgE myeloma. $N$ Engl J Med 1969;281:1217-20.

5. Chusid MJ, Rock AL, Sty JR, Oechler HW, Beste DJ. Kimura's disease: an unusual cause of cervical tumour. Arch Dis Child 1997;77:153-4.

6. Johansson SGO, Bennich H. Immunological studies of an atypical (myeloma) immunoglobulin. Immunology 1967;13:381-94.

7. Allevato PA, Deegan MJ, Chu JW, Perry MB, Barth, CL. A case of IgE myeloma: methodology and review of the literature. Henry Ford Hosp Med J 1984;32:13441.

8. Kairemo KJA, Lindberg M, Prytz M. IgE myeloma: a case presentation and review of the literature. Scand $J$ Clin Lab Invest 1999;59:451-6.

9. Ludwig H, Vormittag W. "Benign" monoclonal IgE gammopathy. Br Med $J$ 1980;23:539-40. 
10. Alexander RL, Stanford TR, Petruska PJ, Tsai CC, Janney CG. A new case of IgE myeloma. Clin Chem 1992;38:2328-32.

11. Macro M, Andre I, Comby E, Cheze S, Chapon F, Ballet JJ, Reman O, Leporrier M, Troussard X. IgE multiple myeloma. Leuk Lymphoma 1999;32:597-603.

12. Vladutiu AO, Kohli RK, Prezyna AP. Monoclonal IgE with renal failure. Am J Med 1976;61:957-62.

13. Proctor SJ, Chawla SL, Bird AG, Stephenson J. Hyperviscosity syndrome in IgE myeloma. $\mathrm{Br}$ Med $\mathrm{J}$ 1984;289:1112.

14. Bemelmans RHH, van Toorn DW, van Leeuwen L, Schaar CG. Long-term complete remission in IgDmyeloma. Eur J Haematol 2006;76:339-41.

15. Grogan TM, Müller-Hermelink HK, Van Camp B, Harris NL, Kyle RA. Plasma cell neoplasms. In:
Jaffe ES, Harris NL, Stein H, Vardiman J, eds. World Health Organization Classification of Tumours: Pathology and Genetics: Tumours of Haematopoetic and Lymphoid Tissues. Lyon: IARC Press, 2000:142-56.

16. Bakshi NA, Bulbranson R, Garstka D, Bradwell AR, Keren DF. Serum free light chain (FLC) measurement can aid capillary zone electrophoresis in detecting subtle FLC-producing M proteins. Am J Clin Pathol 2005;124:214-8.

17. Durie BGM, Kyle RA, Belch A, et al. Myeloma management guidelines: a consensus report from the scientific advisors of the International Myeloma Foundation. Hematol J 2003;4:379-98. 